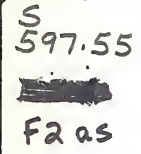

MONTANA DEPARTMENT OF FISH AND GAME HELENA, MONTANA

A SUMMARY OF FISH POPULATION INVESTIGATIONS

IN THE POPLAR RIVER DRAINAGE

JULY 1, 1975 THROUGH MARCH $31,1976^{1 / 1}$

\begin{abstract}
Fisheries studies were conducted on the Poplar River to acquire baseline information needed to evaluate the impacts associated with development of a coal-fired electrical generation complex on the East Fork Poplar River. Walleye was the dominant game fish present. Population estimates for walleye (excluding young-of-the-year) conducted by the mark-and-recapture at two stations revealed 178 walleye per mile in the East Fork and 297 walleye per mile in the main river at the confluence of the East and Middle Forks. Other sport fishes consisted primarily of northern pike, smallmouth bass, and goldeye. Reproductive success of sport fishes and abundance of forage species was determined at nine stations. A total of 1,071 fish were marked to determine the extent of movement for selected sport fishes.
\end{abstract}

\title{
INTRODUCTION
}

The Poplar River is a low-gradient, sinuous prairie stream originating in Saskatchewan. It has a drainage area of 200 square miles. The natural flow pattern is characterized by high spring flows and low summer flows. The physical channel consists primarily of large, deep pools and shallow riffles. Gravel is the dominant streambed material where scouring action occurs; sand, silt, and mud bottoms characterize the large pools. The relatively sparse streambank vegetation consists of grasses, wild rose, and snowberry. Flood plain vegetation consists of grasses and silver sagebrush, except in the extreme lower reaches of the drainage where a variety of shrubs and cottonwoods are abundant.

In 1974, the Saskatchewan Power Corporation announced plans to construct a coal-fired electrical generation complex on the East Fork Poplar River approximately 2 miles north of the U. S. boundary. The proposed development consists of four 300 megawatt (MW) units with a total possible generating capacity of 1,200 MW. The plant, if fully developed, would consume approximately 7 million tons of lignite coal per year. The 1,200 MW complex would require about 1,200 acres of water surface for cooling purposes and approximately 11,000 acre-feet of water per year for replacement of natural and induced evaporation.

1/ Funding assistance was provided by the Environmental Protection Agency.

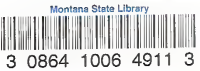


A proposed plan for trans-boundary water apportionment of the entire Poplar River drainage has been'prepared by the Poplar River Task Force. The consumptive needs of this development will exceed the total annual discharge of the East Fork. Development of a cooling reservoir will rely on filling from spring run-off which will drastically reduce flows and alter flow regimes. The recommended flow apportionment for the East Fork only assures delivery of 15 percent of the mean annual flow. It is projected that additional water in the form of spills will be provided in 16 of 44 years. Full development will require that supplemental water be diverted from other sources into the East Fork. The Middle and West Forks have been included in plans for supplementing the industrial water supply of the East Fork. The proposed flow apportionment would provide that a minimum of 60 percent of the Middle Fork and 50 percent of the West Fork natural flow would be delivered to the United States.

The Poplar River Drainage is one of the better warm water stream fisheries in Montana; however, it receives only limited recognition due to the relatively sparse human population in the area. Walleye are the dominant game fish species. Northern pike are widespread in the drainage; and although not as abundant as walleye, they contribute significantly to the creel, possibly due to their higher catchability. Smallmouth bass, introduced in 1967 to supplement the fishery, are reproducing and appear to be establishing fishable populations in some areas. Desirable-size goldeye are present in moderate numbers throughout the system and contribute to the fishery. Forage fishes of numerous species are abundant.

Although Montana contains many prairie streams, few provide a sport fishery. While habitat in the Poplar River is of sufficient quality to maintain a sport fishery, only a small difference in habitat separates this river from numerous other streams which support only non-game species.

Very little information exists regarding the fish population of the Poplar River and its tributaries. Investigations were implemented in 1975 to acquire baseline information needed to evaluate the impact of the Saskatchewan Power Corporation Project on the fish population of the Poplar River Drainage.

\section{FISH POPULATION}

Distribution and Abundance: Nine stations as indicated on Figure 1 were sampled with an alternating current boom-shocker in the fall of 1975. The primary objective was to obtain information on the distribution and abundance of sport fishes. These findings are summarized in Table 1. Due to differences in sampling effort, water conditions, and length of stream sampled, the catches at the various stations are not directly comparable.

Goldeye, although not designated as a game fish by Montana law, were included in the sport fish catch due to their use by some anglers. Goldeye were taken at all sampling locations except the upper East Fork. The relative abundance of goldeye was considerably higher than indicated in Table 1 as there was low efficiency in collecting goldeye stunned during electrofishing. 
$\therefore$

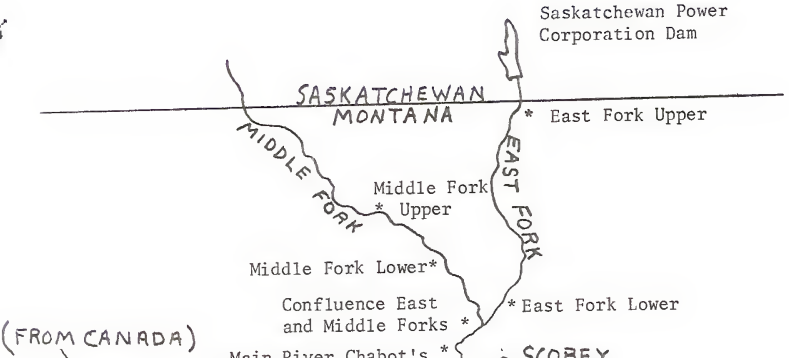

Main River Chabot's

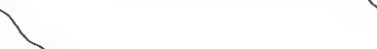

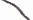
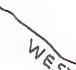

Figure 1. Map of the Poplar River identifying the location of fish population sampling stations which are indicated by an asterisk.

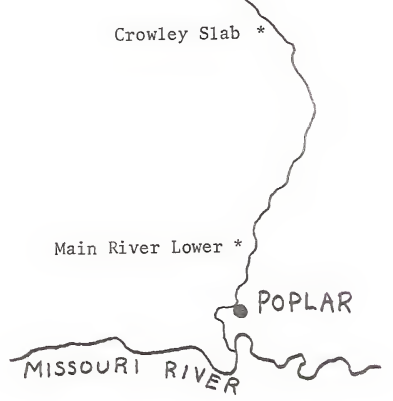


iabie 1. Total number and size (length in inches, weight in pounds) of sport fishes taken with an alternating current boom-shocker at nine locations on the Poplar River, 1975.

\begin{tabular}{|c|c|c|c|c|c|c|c|c|c|c|c|c|c|c|c|c|c|c|c|c|c|c|c|c|c|c|c|}
\hline \multirow{2}{*}{$\underline{\mathrm{s}_{2}} \cdot \underline{1 /}$} & \multicolumn{3}{|c|}{$\begin{array}{c}\text { East Fork } \\
\text { Epper } \\
\text { (1 Sarple) }\end{array}$} & \multicolumn{3}{|c|}{$\begin{array}{l}\text { East Fork } \\
\text { Lower } \\
\text { (4 Samples) }\end{array}$} & \multicolumn{3}{|c|}{$\begin{array}{l}\text { Middle Fork } \\
\text { Upper } \\
\text { (1 Sample) }\end{array}$} & \multicolumn{3}{|c|}{$\begin{array}{l}\text { Confluence East } \\
\text { and Middle Forks } \\
\text { (2 Samples) }\end{array}$} & \multicolumn{3}{|c|}{$\begin{array}{c}\text { Main River } \\
\text { Chabot's } \\
\text { (1 Sample) }\end{array}$} & \multicolumn{3}{|c|}{$\begin{array}{l}\text { Main River } \\
\text { Paulson Slab } \\
\text { (1 Sample) }\end{array}$} & \multicolumn{3}{|c|}{$\begin{array}{l}\text { West Fork } \\
\text { (1 Sample) }\end{array}$} & \multicolumn{3}{|c|}{$\begin{array}{l}\text { Main River } \\
\text { Crowley Slab } \\
\text { (1 Sample) }\end{array}$} & \multicolumn{3}{|c|}{$\begin{array}{c}\text { Main River } \\
\text { Lower } \\
\text { (1 Sample) }\end{array}$} \\
\hline & No. & L. & wt. & ทio. & L. & Wt. & No. & L. & Wt. & No. & L. & wt. & No. & L. & Wt. & No. & L. & ht. & No. & L. & Wt. & No. & L. & Wt. & No. & L. & Wt. \\
\hline $\begin{array}{l}\text { HE } \\
1+ \\
\text { older }\end{array}$ & -- & -- & -- & 123 & 12.5 & 0.71 & 16 & 14.3 & 1.02 & 146 & 12.2 & 0.61 & 57 & 11.2 & 0.47 & 43 & 13.0 & 0.72 & 45 & 13.8 & 1.08 & 18 & 12.9 & 0.80 & 9 & 12.8 & 0.68 \\
\hline $\begin{array}{l}W E \\
Y-Y\end{array}$ & 4 & 5.7 & - & $\begin{array}{l}20 \\
43\end{array}$ & $\begin{array}{l}5.0 \\
\mathrm{NA}\end{array}$ & -- & 5 & 4.2 & - & 13 & 4.4 & -- & 10 & 4.5 & -- & 4 & 4.8 & -- & 8 & 5.4 & -- & 4 & 5.4 & -- & 4 & 5.0 & -- \\
\hline $\begin{array}{l}\text { NP } \\
1+ \\
\text { older }\end{array}$ & -- & -- & - & 4 & 23.5 & 3.38 & - & -- & - & - & -- & - & -- & - & - & 2 & 21.9 & 2.45 & -- & - & -- & 3 & 20.3 & 2.02 & 1 & 18.8 & 1.23 \\
\hline $\begin{array}{l}\text { NP } \\
Y-Y\end{array}$ & -- & -- & -- & -- & - & -- & -- & -- & -- & -- & -- & -- & 7 & 11.3 & 0.33 & 16 & 10.0 & 0.21 & - & -- & -- & 7 & 10.1 & 0.24 & 8 & 10.0 & 0.21 \\
\hline SA & -- & -- & -- & -- & -- & -- & -- & -- & - & 1 & 13.4 & 0.60 & - & - & - & -- & - & -- & - & -- & -- & 1 & 13.6 & 0.70 & 1 & 17.5 & 1.47 \\
\hline $\begin{array}{l}\text { SMB } \\
1+ \\
\text { older }\end{array}$ & -- & -- & -- & - & -- & - & -- & - & -- & -- & -- & -- & -- & -- & -- & 4 & 7.5 & 0.27 & 7 & 8.2 & 0.33 & 3 & 7.7 & 0.28 & 6 & 8.0 & 0.32 \\
\hline $\begin{array}{l}S M B \\
Y-Y\end{array}$ & -- & -- & -- & -- & -- & - & -- & - & -- & -- & -- & -- & -- & -- & -- & 5 & 3.2 & 0.02 & 1 & 3.1 & 0.02 & -- & -- & - & - & - & -- \\
\hline$G E$ & -- & -- & -- & 10 & 13.2 & 0.74 & 2 & 13.4 & 0.89 & 33 & 13.3 & 0.75 & 33 & 13.0 & 0.73 & 35 & 12.7 & 0.61 & 19 & 13.5 & 0.80 & 14 & 12.1 & 0.57 & 20 & 11.9 & 0.51 \\
\hline
\end{tabular}

1/ Abbreviations: hE, Walleye; NP, Northern pike; SA, Sauger: SMB, Smallmouth bass; GE, Goldeye; Y-Y, young-of-the-year; SP., Species. 
Walleye were the dominant game fish taken; however, numbers were low at the upper East Fork station. Sampling in this area indicated walleye adults do not commonly inhabit this stretch of river in appreciable numbers as residents, but do utilize this portion and upstream segments for spawning. Turbid water conditions during sampling on the Middle Fork curtailed sampling success. Walleye young-of-the-year were found throughout the entire area sampled.

Catches for northern pike were relatively low. Northerns appeared to be distributed throughout the system, but due to the small numbers taken only limited information was obtained. The greatest numbers taken consisted of young-of-the-year. Spring flows were above normal in 1975 which may have provided better than average spawning conditions for northern pike.

Smallmouth bass were taken only in the West Fork and mainstem portions of the drainage downstream from Scobey. In 1967, approximately 4,000 fingerlings $(2$-inch) smallmouth were stocked to establish a population. In addition, 150 yearlings $(6$-inch) were stocked in 1968. Most of the stocking was conducted in the West Fork; however, releases were also made at the Paulson Slab on the main river. Most of the smallmouth collected were young-ofthe-year and yearlings. Indications are that the relatively few adults present are spawning successfully and therefore the population should increase significantly in the future when additional fish reach maturity.

During electrofishing operations an effort was made to collect only fishes of significant sport value. However, in an effort to acquire broad information on population composition, records were also maintained on all species observed within the electrical sampling field. Information recorded in this manner did not include small individuals less than 6 inches in length. As indicated in Table 2, the number of species taken increased at downstream locations. Only white sucker, shorthead redhorse, and carp were common throughout the drainage.

In an effort to obtain quantitative information on portions of the drainage to be immediately impacted by development, population estimates were conaucted by the mark-and-recapture method at two stations. Walleye (excluding young-of-the-year) populations were estimated at one site on the East Fork (lower) and one site on the mainstem immediately below the confluence of the East and Middle Forks. Estimates were made utilizing Chapman's modification of the Petersen formula (Ricker, $1975 \mathrm{Pg}$. 78):

$$
N=(M+1) \quad(C+1) \quad \text { where }
$$

\section{$R+1$}

$\mathrm{N}=$ Population estimate.

$\mathrm{M}=$ Number of fish marked.

$\mathrm{C}=$ Number of fish in recapture sample.

$R=$ Number of marked fish in recapture sample (C). 
Table 2. Numbers and species of fish observed (but not collected) while sampling with an alternating current boom-shocker at nine stations on the Poplar River, 1975.

\begin{tabular}{|c|c|c|c|c|c|c|c|c|c|}
\hline Species & $\begin{array}{l}\text { East } \\
\text { Fork } \\
\text { Upper } \\
\end{array}$ & $\begin{array}{l}\text { East } \\
\text { Fork } \\
\text { Lower }\end{array}$ & $\underset{\substack{\text { Middle } \\
\text { Fork }}}{\underline{1 /}}$ & $\begin{array}{l}\text { Conflu. } \\
\text { East \& } \\
\text { Middle } \\
\text { Forks }\end{array}$ & $\begin{array}{c}\text { Main } \\
\text { River } \\
\text { Chabot's }\end{array}$ & $\begin{array}{c}\text { Main } \\
\text { River } \\
\text { Paulson } \\
\text { Slab } \\
\end{array}$ & $\begin{array}{l}\text { West } \\
\text { Fork }\end{array}$ & $\begin{array}{c}\text { Main } \\
\text { River } \\
\text { Crowley } \\
\text { Slab }\end{array}$ & $\begin{array}{l}\text { Main } \\
\text { River } \\
\text { Lower } \\
\end{array}$ \\
\hline Carp & 15 & 3 & 2 & 9 & 29 & 33 & 35 & 16 & 31 \\
\hline $\begin{array}{l}\text { River } \\
\text { carpsucker }\end{array}$ & -- & -- & - & -- & -- & 20 & -- & 20 & 101 \\
\hline $\begin{array}{l}\text { Bigmouth } \\
\text { buffalo }\end{array}$ & -- & -- & -- & - & -- & -- & -- & -- & 1 \\
\hline $\begin{array}{l}\text { Shorthead } \\
\text { redhorse }\end{array}$ & 20 & 1 & 5 & 24 & 29 & 191 & 74 & 59 & 89 \\
\hline $\begin{array}{l}\text { Longnose } \\
\text { sucker }\end{array}$ & -- & -- & -- & -- & -- & - & - & - & 1 \\
\hline $\begin{array}{l}\text { White } \\
\text { sucker }\end{array}$ & 2,984 & 168 & 40 & 455 & 242 & 378 & 349 & 83 & 12 \\
\hline $\begin{array}{l}\text { Black } \\
\text { bullhead }\end{array}$ & - & - & - & -- & -- & - & 1 & - & 1 \\
\hline $\begin{array}{l}\text { Channel } \\
\text { catfish }\end{array}$ & -- & -- & -- & - & -- & -- & -- & -- & 1 \\
\hline Stonecat & - & -- & -- & -- & - & 6 & 3 & -- & - \\
\hline $\begin{array}{l}\text { Yellow } \\
\text { perch }\end{array}$ & - & - & -- & $-\infty$ & - & $-\infty$ & - & - & 2 \\
\hline $\begin{array}{l}\text { Freshwater } \\
\text { drum }\end{array}$ & -- & -- & -- & - & - & -- & -- & -- & 1 \\
\hline
\end{tabular}

I/ Represents fish collected. 
This work revealed a population of 178 walleye per mile in the East Fork and 297 walleye per mile at the confluence of the East and Middle Forks. Population estimates were not made for goldeye, northern pike, and smallmouth bass because low populations or failure to recapture sufficient numbers of marked fish did not satisfy statistical criteria.

Reproduction: Reproductive success of sport fishes and abundance of forage species was determined at nine stations by sampling in the fall with a $4-$ x 25-foot seine of $\frac{1}{4}$-inch square mesh. A summary of abundance and distribution of small and/or young fish is presented in Table 3. Each sample designated on this table represents one seine haul through 25-50 feet of stream.

The best catch for young-of-the-year walleye occurred at the upper Middle Fork station. It was also apparent that the East Fork provides important walleye spawning habitat. Young-of-the-year northern pike were only taken in the mainstem river below the confluence of the East and Middle Forks. However, reports from anglers indicate that northern pike are more common in the Middle Fork than was indicated at the sampling station.

Lake chub and white sucker were key forage species throughout the drainage. Fathead minnows and longnose dace were common at most collection sites. The large numbers of northern redbelly dace and brook stickleback taken at the upper East Fork station appear to be associated with channel eutrophication conditions. In general the abundance and distribution of the flathead chub was similar to that of the emerald shiner which appeared to be confined to the mainstem river and lower West Fork.

Movement: Walleye and northern pike are not native to the Poplar River system and events responsible for development of their populations are not known. Personal communication with "oldtimers" who have resided along the river for up to 70 years indicate these species were not present historically. Limited walleye stocking conducted by the Montana Department of Fish and Game from the mid 1950's to the early 1960's may have been a contributing factor; however, population increases of walleye and northern pike during this period in the Missouri River undoubtedly had a major role in establishing populations in the Poplar River.

In an effort to determine the extent of movement and migration for selected sport fishes, within the Poplar River system, marking was conducted in the spring and fall of 1975 by tagging and fin excision. The objectives of this work were to: 1) determine residence within the system, 2) identify spawning migrations, and 3) determine the contribution, if any, from migration of Missouri River fishes.

A total of 1,071 fish were marked for study, of which 733 were walleye as summarized in Table 4. All tags utilized were numbered Floy anchor tags. Walleye tagging was confined to adults and some yearlings in the 7 - to 10inch size class. Goldeye were marked by fin-clipping to minimize stress by handling.

Since most fish marking was in the fal1 of 1975 and comparatively few were marked the previous spring, only limited numbers of marked fish were available for study during the period covered by this report. Fall sampling 
Tatle 3. A sumary of fish collected by sampling with a 4- $x$ 25-foot seine in the Poplar River, 1975.

\begin{tabular}{|c|c|c|c|c|c|c|c|c|c|c|c|}
\hline Species & $\begin{array}{c}\text { Size } \\
\text { (1nches) }\end{array}$ & $\begin{array}{r}\mathrm{Ea} \\
(4 \\
\end{array}$ & $\begin{array}{l}\text { st Fork } \\
\text { Upper } \\
\text { Samples) }\end{array}$ & $\begin{array}{c}\text { East Fork } \\
\text { Lower } \\
\text { (6 Samples) }\end{array}$ & $\begin{array}{c}\text { Middle Fork } \\
\text { Upper } \\
\text { (10 Samples) }\end{array}$ & $\begin{array}{c}\text { Middle Fork } \\
\text { Lower } \\
\text { (5 Samples) }\end{array}$ & $\begin{array}{c}\text { Mala River } \\
\text { Chabot's } \\
\text { (3 Samples) }\end{array}$ & $\begin{array}{l}\text { Main River } \\
\text { Paulson Slab } \\
\text { (5 Samples) }\end{array}$ & $\begin{array}{l}\text { West Fork } \\
\text { (4 Samples) }\end{array}$ & $\begin{array}{c}\text { Ma1n River } \\
\text { Crowley S1ab } \\
\text { (3 Samples) }\end{array}$ & $\begin{array}{c}\text { Main River } \\
\text { Lower } \\
\text { (3 Samples) }\end{array}$ \\
\hline Northern pike & $8-11$ & & - & - & - & -- & 2 & 2 & $\cdots$ & 3 & 2 \\
\hline Carp & $1-2$ & & 4 & -- & -- & -- & - & - & -- & - & - \\
\hline Creek chub & & & 2 & 4 & - & 1 & -- & - & 1 & -- & - \\
\hline $\begin{array}{l}\text { Northern redbelly } \\
\text { dace }\end{array}$ & & & 1,311 & - & - & - & - & - & 18 & - & - \\
\hline Flathead chub & & & - & - & -- & - & 11 & 42 & 96 & 189 & 213 \\
\hline Lake chub & & & 297 & 319 & 406 & 195 & 110 & 99 & 310 & 206 & 14 \\
\hline Emerald shiner & & & -- & 7 & -- & -- & 8 & 357 & 114 & 239 & 209 \\
\hline Brassy minnow & & & * & - & -- & -- & - & - & -- & 12 & - \\
\hline $\begin{array}{l}\text { Silvery/plains } \\
\text { minnow }\end{array}$ & & & 96 & - & 5 & - & -- & - & 1 & 1 & 20 \\
\hline Fathead minnow & & & 96 & 18 & 110 & 13 & - & - & 19 & 1 & 3 \\
\hline Longnose dace & & & 9 & 72 & 16 & 34 & 14 & 1 & 60 & 12 & 8 \\
\hline River carpsucker & $1-3$ & & - & -- & - & -- & - & - & - & 2 & - \\
\hline Bigmouth buffalo & $1-3$ & & - & - & - & - & - & -- & - & - & 6 \\
\hline Shorthead redhorse & $\begin{array}{l}3-6 \\
6-9\end{array}$ & & -- & 11 & $\begin{array}{l}84 \\
--\end{array}$ & -- & $\begin{array}{l}1 \\
4\end{array}$ & $\begin{array}{l}16 \\
16\end{array}$ & -- & -5 & $\underline{5}$ \\
\hline White sucker & $\begin{array}{l}1-6 \\
6-10\end{array}$ & & $\begin{array}{r}163 \\
2\end{array}$ & 342 & $\begin{array}{l}348 \\
308\end{array}$ & $\overline{10}$ & $\begin{array}{l}30 \\
14\end{array}$ & $\begin{array}{l}17 \\
18\end{array}$ & $\begin{array}{l}60 \\
18\end{array}$ & $\begin{array}{r}42 \\
5\end{array}$ & $\begin{array}{r}26 \\
5\end{array}$ \\
\hline Brook stickleback & & & 211 & 3 & -- & 12 & 5 & - & - & - & - \\
\hline Smallmouth bass & $3-8$ & & - & - & - & -- & - & 3 & - & -- & -- \\
\hline Walleye & $\begin{array}{l}4-6 \\
8-14\end{array}$ & & - & $\begin{array}{l}9 \\
1\end{array}$ & $\begin{array}{r}40 \\
4\end{array}$ & $\begin{array}{r}8 \\
--\end{array}$ & $\begin{array}{l}1 \\
1\end{array}$ & $-\overline{1}$ & $=$ & $\underline{2}$ & 1 \\
\hline Iowa darter & & & 13 & - & 1 & 2 & - & - & - & $\ldots$ & - \\
\hline
\end{tabular}

* Identification error may have Included brassy minnows with silvery/platns minnows. 
Table 4. A summary of fish marked by tagging and fin-clipping at various locations in the Poplar River, 1975.

\begin{tabular}{|c|c|c|c|c|c|c|c|c|c|}
\hline \multirow[b]{2}{*}{ Station } & \multicolumn{2}{|c|}{ Walleye } & \multicolumn{2}{|c|}{ Northern Pike } & & \multicolumn{2}{|c|}{ Sauger } & \multicolumn{2}{|c|}{ Goldeye } \\
\hline & $\mathrm{Tag}$ & Clip & Tag & Clip & & Tag & Clip & Tag & Clip \\
\hline East Fork & 109 & 113 & 4 & - & & - & - & - & 12 \\
\hline Middle Fork & 28 & 75 & 1 & -- & & - & - & - & 5 \\
\hline $\begin{array}{l}\text { Confluence } \\
\text { East and } \\
\text { Middle Forks }\end{array}$ & 135 & 54 & 1 & - & & 1 & - & - & 73 \\
\hline $\begin{array}{l}\text { Main River } \\
\text { Chabot's }\end{array}$ & 41 & 35 & - & 10 & & - & - & - & 88 \\
\hline West Fork & 45 & 11 & - & -- & & - & - & - & 32 \\
\hline $\begin{array}{l}\text { Main River } \\
\text { Paulson Slab }\end{array}$ & 39 & 11 & - & 17 & - & - & - & - & 35 \\
\hline $\begin{array}{l}\text { Main River } \\
\text { Crowley Slab }\end{array}$ & 16 & 6 & 3 & 10 & & 1 & - & - & 14 \\
\hline $\begin{array}{l}\text { Main River } \\
\text { Lower }\end{array}$ & 9 & 6 & - & 10 & & 1 & - & - & 20 \\
\hline Totals & 422 & 311 & 9 & 47 & & 3 & - & - & 279 \\
\hline
\end{tabular}


in 1975 provided movement observations on five walleye and one northern pike marked in the spring. Three of the walleye were recaptured at the same location where marking occurred, and two had moved upstream 4 to 6 miles. The northern pike had moved downstream approximately 2 miles.

Fishermen reported eight walleye tag returns. Five of these tagged in the fall of 1975 were caught within one month near the release site. Three reports of tagged fish were made in the spring of 1976 . One of these was caught at the lower East Fork station and had been tagged at that location in the spring of 1975. The second was caught 6 miles north of Poplar and had been tagged at the Crowley Slab in the fall of 1975 . This represents a downstream movement of approximately 25 river miles. The third was caught just west of Scobey and had been tagged in the fall of 1975 at the confluence of the East and Middle Forks which represents a downstream movement of several miles.

Electrofishing during the spring of 1976 at the lower East Fork station captured one marked goldeye which had been released at this site in the fall of 1975 .

Age and Growth: Scale samples were collected from various species for aging to facilitate data arrangement by year-class and provide an additional dimension to fish population knowledge. Back-calculations were made using an intercept at zero. A summary of age and growth findings is presented in Table 5 .

Growth rates for walleye, northern pike, and smallmouth bass were good overal1. As adult smallmouth bass become more abundant, future age determinations will be desirable. Some difficulty was encountered when identifying annuli on goldeye scales and this effort should be repeated with additional samples. Growth for goldeye was similar to, but slightly poorer than that reported for the Missouri River by Bill Hill (1965).

\section{CONCLUSIONS AND RECOMMENDATIONS}

The low, stable flows proposed for the East Fork will dramatically alter the natural flow regimen of this river. It is anticipated that this condition will greatly impair walleye reproduction and contribute to channel eutrophication.

The Middle Fork contains one of the most important segments of the sport fishery. Potential flows within the proposed allotments should be adequate to maintain walleye. However, the water apportionment does not indicate the extent or timing of releases, and therefore, meaningful evaluations of impacts cannot be ascertained. Flow regimens that generally resemble existing conditions, particularly with reference to spring flow are essential.

An immediate need exists to obtain improved quantitative information on the fish population in the East Fork where near future impacts are anticipated. Additional population estimates should be secured for adult sport fishes and 
Table 5. A summary of growth rate information for several species in the Poplar River, 1975. The number of fish sampled is given in parenthesis.

\begin{tabular}{|c|c|c|c|c|c|c|c|}
\hline \multirow{2}{*}{$\begin{array}{l}\text { Species \& } \\
\text { Station }\end{array}$} & \multicolumn{7}{|c|}{ Age Class } \\
\hline & $I$ & II & III & IV & $\mathrm{V}$ & VI & VII \\
\hline \multicolumn{8}{|l|}{ Wa11eye: } \\
\hline East Fork & $\begin{array}{l}4.2 \\
(3)\end{array}$ & $\begin{array}{l}8.8 \\
(2)\end{array}$ & $\begin{array}{c}11.4 \\
(1)\end{array}$ & $\begin{array}{c}13.9 \\
(1)\end{array}$ & $\begin{array}{c}17.5 \\
(1)\end{array}$ & $\begin{array}{c}19.7 \\
(1)\end{array}$ & \\
\hline Middle Fork & $\begin{array}{l}5.0 \\
(11)\end{array}$ & $\begin{array}{l}8.9 \\
(7)\end{array}$ & $\begin{array}{c}11.1 \\
(7)\end{array}$ & $\begin{array}{c}13.5 \\
(7)\end{array}$ & $\begin{array}{c}15.7 \\
(6)\end{array}$ & $\begin{array}{c}16.9 \\
(2)\end{array}$ & \\
\hline West Fork & $\begin{array}{l}4.9 \\
(13)\end{array}$ & $\begin{array}{l}9.0 \\
(13)\end{array}$ & $\begin{array}{c}11.5 \\
(7)\end{array}$ & $\begin{array}{c}14.0 \\
(5)\end{array}$ & $\begin{array}{c}16.0 \\
(5)\end{array}$ & $\begin{array}{c}17.8 \\
(2)\end{array}$ & \\
\hline $\begin{array}{l}\text { Confluence } \\
\text { East \& Middle } \\
\text { Forks }\end{array}$ & $\begin{array}{l}4.7 \\
(29)\end{array}$ & $\begin{array}{l}8.8 \\
(25)\end{array}$ & $\begin{array}{l}11.6 \\
(13)\end{array}$ & $\begin{array}{l}13.5 \\
(12)\end{array}$ & $\begin{array}{c}15.8 \\
(7)\end{array}$ & $\begin{array}{c}16.5 \\
(4)\end{array}$ & $\begin{array}{c}18.3 \\
(3)\end{array}$ \\
\hline $\begin{array}{l}\text { Combined } \\
\text { Average }\end{array}$ & $\begin{array}{l}4.7 \\
(56)\end{array}$ & $\begin{array}{l}8.9 \\
(47)\end{array}$ & $\begin{array}{l}11.5 \\
(28)\end{array}$ & $\begin{array}{l}13.6 \\
(25)\end{array}$ & $\begin{array}{l}15.9 \\
(19)\end{array}$ & $\begin{array}{c}17.3 \\
(9)\end{array}$ & $\begin{array}{c}18.3 \\
(3)\end{array}$ \\
\hline
\end{tabular}

$\begin{array}{lrr}\text { Smallmouth } & 3.6 & 8.2 \\ \underline{\text { bass }} & (17) & (1)\end{array}$

Northern $\quad 11.1$

pike (3)

$\begin{array}{lllllllll}\text { Goldeye } & 3.2 & 6.5 & 8.7 & 10.2 & 11.5 & 12.2 & 13.4 & 14.4\end{array}$

$\begin{array}{llllllll}(22) & (22) \quad(22) \quad(22) \quad(21) \quad(10) \quad \text { (4) }\end{array}$


efforts should concurrently be undertaken to identify spawning and nursery areas for walleye and quantify reproduction. Early spring sampling should be conducted to evaluate and identify key spawning sites.

\section{LITERATURE CITED}

Hi11, Willaim J. 1965. Observations on the Life History and Movement of the Goldeye Hiodon alosoides in Montana. Proc. Mont. Acad. Sci. 26, p. 45-53.

Ricker, W. E. 1975. Computation and Interpretation of Biological Statistics of Fish Populations. Fish Res. Bd. Can., Bu11. 191. $382 \mathrm{p}$.

Prepared by Robert G. Needham

Date June 11,1976 